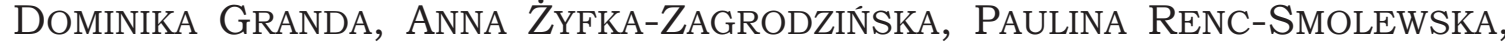 \\ MARIA SZMIDT, ElŻBIETA WIERZBICKA, ANNA BRZOZOWSKA
}

Katedra Żywienia Człowieka

Wydział Nauk o Żywieniu Człowieka i Konsumpcji

Szkoła Główna Gospodarstwa Wiejskiego w Warszawie

Nowoursynowska 159C, 02-776 Warszawa

E-mail: dominika_granda@sggw.pl

\title{
WITAMINA D U OSÓB STARSZYCH - FUNKCJE, RYZYKO NIEDOBORU I WIEDZA SENIORÓW
}

\section{WPROWADZENIE}

Witamina D, szczególnie jej aktywna hormonalna postać, jest zaangażowana w liczne procesy fizjologiczne, m.in. homeostazę wapniowo-fosforowa i metabolizm kości, funkcjonowanie układu odpornościowego i endokrynnego, a także pracę mózgu. Jej głównym źródłem dla organizmu człowieka jest synteza endogenna, która może pokryć około 90\% zapotrzebowania osób dorosłych. W skórze pod wpływem promieniowania ultrafioletowego UVB z 7-dehydrocholesterolu powstaje cholekalcyferol, ulegajaccy następnie hydroksylacji w watrobie do $25(\mathrm{OH}) \mathrm{D}$ i przekształceniu w nerkach do formy aktywnej 1,25(OH) $)_{2} \mathrm{D}$ (Holick 2017). Jednak zmiana stylu życia zwiazana $z$ dłuższym przebywaniem w pomieszczaniach, a także obawa przed skutkami nadmiernego nasłonecznienia powoduja, że synteza w skórze nie jest wystarczajaca. Dobrym źródłem witaminy D są tłuste ryby, takie jak łosoś, śledź, makrela, a także masło, jaja i podroby. Do produktów obligatoryjnie wzbogacanych $\mathrm{w}$ witaminę $\mathrm{D}$ należą margaryny $\mathrm{i}$ inne tłuszcze do smarowania $z$ wyjątkiem masła (SZYMAŃSKI i współaut. 2015). Na rynku krajowym pojawiło się także wiele produktów dobrowolnie wzbogaconych tą witamina, w tym masło, mleko, jogurty, serki, płatki śniadaniowe, batoniki, napoje i soki. Jednak racje pokarmowe również nie dostarczaja odpowiednich jej ilości, dlatego eksperci zalecaja stosowanie suplementów diety, w różnych dawkach i w różnych okresach roku dla poszczegól- nych grup populacyjnych (RUSIŃSKA i współaut. 2018a, b).

Niedobór witaminy D to powszechny problem na całym świecie; szacuje się, że mniej niż połowa populacji globu ma odpowied$\mathrm{ni}$ stan zaopatrzenia organizmu $\mathrm{w}$ witaminę D. Według rekomendacji Polskiego Towarzystwa Pediatrii, Endokrynologii i Cukrzycy oraz Panelu Ekspertów z 2018 r. stężenie 25(OH)D w osoczu krwi $<50 \mathrm{nmol} / 1 \quad(<20$ $\mathrm{ng} / \mathrm{ml}$ ) oznacza niedobór witaminy $\mathrm{D}$, natomiast stężenie optymalne wynosi $75-125$ nmol/1 (30-50 ng/ml) (RUSIŃSKA i współaut. 2018a, b). Do osób szczególnie narażonych na ryzyko niedoboru należa dzieci $z$ niska masa urodzeniowa, kobiety w ciaży, osoby starsze oraz osoby emigrujące do krajów zachodnich (VAN ScHOOR i LIPS 2017). Seniorzy sa grupa o podwyższonym ryzyku wystapienia niedoboru witaminy $\mathrm{D}$ ze względu na obniżenie efektywności syntezy skórnej, wynikajacej $z$ niższego, nawet o $75 \%$ poziomu 7-dehydrocholesterolu w skórze, oraz zmianę trybu życia, związanej $\mathrm{z}$ ograniczeniem aktywności fizycznej poza domem, noszeniem ubrań zakrywających większość powierzchni ciała i stosowaniem kremów $z$ filtrami ochronnymi. Obniżone stężenie krażącego we krwi metabolitu 25(OH)D u osób starszych może także wynikać ze zmniejszonego wchłaniania witaminy $\mathrm{D} \mathrm{w}$ przewodzie pokarmowym oraz sekwestracji w tkance tłuszczowej. Również choroby nabyte, np. niedoczynność tarczycy, moga zwiększać metabolizm 25(OH) $\mathrm{D}$, obniżając stężenie kalcydiolu we krwi, a choroby watroby i nerek zmniejszajac synte- 
zę aktywnych jej metabolitów (GRYGIEL-GóRNIAK I PUSZCZEWICZ 2014).

$\mathrm{Na}$ podstawie badań przekrojowych $\mathrm{w}$ ramach projektu PolSenior stwierdzono, że w Polsce problem niewystarczajacego zaopatrzenia organizmu $\mathrm{w}$ witaminę $\mathrm{D}$ dotyczy ponad $80 \%$ osób w wieku $\geq 65$ lat (WYSKIDA i współaut. 2018). Głównym skutkiem niedoboru witaminy $\mathrm{D}$ u seniorów jest pogorszenie stanu układu kostnego oraz osteoporoza, zwiększone ryzyko upadków i zaburzenia zdolności poznawczych, w tym również choroba Alzheimera. Niektóre badania wskazuja także na częstsze występowanie nowotworów u osób ze złym stanem zaopatrzenia organizmu $\mathrm{w}$ witaminę $\mathrm{D}$. Do czynników socjo-demograficznych, które sa zwiazane $z$ większym ryzykiem niedoboru wśród seniorów należą m.in. niski status ekonomiczny, mała aktywność fizyczna, złe warunki środowiskowe, palenie tytoniu i niższy poziom wykształcenia (WYSKIDA i współaut. 2017). Obecnie osobom w wieku 65-75 lat zaleca się całoroczna suplementację witamina D $\mathrm{w}$ dawce 800-2000 j.m./dzień (20-50 $\mu \mathrm{g} /$ dzień), zależnie od masy ciała i spożycia $z$ dieta. Seniorzy $z$ otyłościa powinni zastosować wyższa dawkę 1600-4000 j.m./dzień (40-100 $\mu \mathrm{g} /$ dzień). Osobom w wieku 75+ zaleca się całoroczna suplementację witaminą D w dawce 2000-4000 j.m./dzień (50$100 \mu \mathrm{g} /$ dzień), natomiast $\mathrm{w}$ przypadku osób

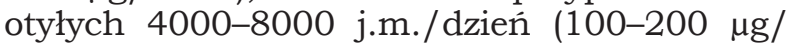
dzień) (RUSIŃSKA i współaut. 2018a, b). Pomimo tego, że obecnie większym problemem wydaje się być niedobór witaminy $\mathrm{D}$, warto też zwrócić uwagę na możliwe konsekwencje nadmiaru. U osób starszych długotrwałe stosowanie wysokich dawek cholekalcyferolu może prowadzić do utraty masy kostnej, hiperkalciurii $i$ niewydolności nerek, stą konieczność stosowania suplementacji pod kontrola lekarska (LANSKE i RAZZAQUE 2007). Aby ograniczyć możliwość nadmiernego stosowania suplementów witaminy D ustalono (m.in. European Food Safety Authority na terenie Unii Europejskiej i Institute of Medicine w USA) tzw. górna tolerowana wartość podaży dla zdrowej populacji ogólnej, która dla witaminy D wynosi 4000 j.m./dzień (100 $\mu \mathrm{g} /$ dzień) w przypadku osób dorosłych i starszych. Nie należy jednak mylić tego poziomu $\mathrm{z}$ dawkami stosowanymi $\mathrm{w}$ kontrolowanym przez lekarza procesie leczenia niedoboru (RUSIŃSKA i współaut. 2018a, b).

\section{WITAMINA D A METABOLIZM KOŚCI}

Stan zaopatrzenia organizmu w witaminę D wpływa na mineralizacje kośćca, szybkość obrotu kostnego i częstość wystẹpowania złamań. Aktywny metabolit witaminy D, czyli $1,25(\mathrm{OH})_{2} \mathrm{D}$, stymuluje otwieranie kanałów wapniowych $\mathrm{w}$ błonach komórkowych enterocytów oraz syntezę białek wiążących wapń, co bezpośrednio wpływa na wzrost jelitowego wchłaniania wapnia. Dodatkowo, niski poziom $1,25(\mathrm{OH})_{2} \mathrm{D}$ powoduje wzrost stężenia parathormonu (PTH), który stymuluje nerkowe przemiany $25(\mathrm{OH}) \mathrm{D}$ do aktywnej formy $1,25(\mathrm{OH})_{2} \mathrm{D}$ oraz prowadzi do zwiększonego obrotu kostnego, czego konsekwencja jest utrata masy kostnej (LIPS i VAN ScHOOR 2011a, b). Liczne badania epidemiologiczne wykazały, że wyższy poziom $25(\mathrm{OH})$ $D$ we krwi jest zwiazany $z$ większa gęstościa kości, podobnie wiele badań interwencyjnych wskazuje na poprawę stanu kości w wyniku suplementacji witamina D (BRUYERE i współaut. 2014). Jednak na podstawie systematycznego przeglądu piśmiennictwa uwzględniającego wyniki 23 badań interwencyjnych $z$ udziałem 4082 osób (średni wiek badanych wynosił 59 lat) REID i współaut. (2014) nie stwierdzili istotnej poprawy parametrów gęstości kości w wyniku suplementacji witamina $\mathrm{D}$, mimo stosunkowo długiego trwania interwencji - średnio 23,5 miesiaca. Natomiast trwająca rok interwencja, polegająca na modyfikacji sposobu żywienia w kierunku diety śródziemnomorskiej łącznie $z$ suplementacja witaminy $D$, istotnie zredukowała tempo utraty masy kostnej u osób z osteoporoza (JENNINGs i współaut. 2018). Może to wskazywać na konieczność jednoczesnej suplementacji witaminy D oraz innych składników lub racjonalizacji diety. Należy jednak zaznaczyć, że niedobór witaminy D u osób starszych w kontekście stanu układu kostno-szkieletowego może prowadzić do osteomalacji, wtórnej nadczynności przytarczyc, obniżenia gęstości mineralnej kości oraz zwiększonego ryzyka złamań (HiLl i współaut. 2013).

\section{WITAMINA D A RYZYKO UPADKÓW I SIŁA MIEŚNI}

Upadki to poważny problem geriatryczny, zaliczany do tzw. wielkich zespołów geriatrycznych. Szacuje się, że upadki dotycza 30-46\% seniorów w każdym roku, przy czym wśród kobiet sa o 20\% częstsze niż wśród mężczyzn. Do upadku dochodzi w wyniku oddziaływania czynników predysponujących (np. starszy wiek, zaburzenia funkcji motorycznych, problemy $z$ równowaga, choroby przewlekłe) oraz wyzwalajacych (np. odwodnienie, problemy $z$ układem moczowym, stosowanie niektórych leków). Jak podaja eksperci World Health Organization, rocznie w wyniku upadków umiera około 500.000 osób na całym świecie, co wskazuje na potrzebę znalezienia i wdrożenia skutecznych działan 
profilaktycznych, których przykładem wydaje się być suplementacja witamina D (DHALIWAL i AloIA 2017). Dotychczas uważano, że korzystne działanie cholekalcyferolu wynika $Z$ jego wpływu na układ kostno-szkieletowy i regulacje poziomu $\mathrm{PTH}$, jednak ostatnie doniesienia sugeruja występowanie bezpośredniego oddziaływania witaminy $\mathrm{D}$ na włókna mięśniowe typu II. Witamina $\mathrm{D}$ powoduje poprawę wytrzymałości prostowników kolan oraz poprawę wyników testów badających siłę mięśni dłoni i przedramienia oraz szybkość chodu (HALFon i współaut. 2015). W badaniach obserwacyjnych stwierdzono, że przy niskim poziomie $25(\mathrm{OH}) \mathrm{D}$ w osoczu krwi ryzyko upadków u osób starszych było większe, natomiast wyniki badań interwencyjnych $z$ zastosowaniem suplementów witaminy D nie sa jednoznaczne. Badania, w których uczestnicy przyjmowali codziennie witaminę D wskazuja na zmniejszenie ryzyka upadków, jednak przy zastosowaniu dawek bolusowych (np. w formie zastrzyku raz w miesiącu w dawce 24000 j.m. (600 $\mu \mathrm{g})$ lub 60.000 j.m. (1500 $\mu \mathrm{g})$, co stanowi ekwiwalent dziennych dawek 800-2000 j.m. (20$50 \mu \mathrm{g})$, ryzyko upadków wzrastało. Dokładne mechanizmy tego zjawiska nie sa znane. Przypuszcza się, że może być to zwiazane $z$ toksycznym oddziaływaniem wysokich dawek witaminy $\mathrm{D}$ na receptory $1,25(\mathrm{OH})_{2} \mathrm{D}$ licznie występujące w móżdżku (GALLAGHER 2016).

\section{WITAMINA D A RYZYKO NOWOTWORÓW}

Witamina D, a szczególnie jej aktywna forma $1,25(\mathrm{OH})_{2} \mathrm{D}$, wykazuje działanie antynowotworowe za pośrednictwem kilku różnych mechanizmów: hamuje nadmierna proliferację komórek, stymuluje apoptozę i różnicowanie się komórek, a także hamuje procesy zapalne, reguluje ekspresję mRNA i moduluje szlaki sygnałowe (BANDERA MERCHAN i współaut. 2017). Wyniki badań wskazują także na jej istotna rolę w toczacym się już procesie nowotworowym: kalcytriol może hamować proces inwazji i powstawania przerzutów, a także zmniejsza intensywność powstawania sieci naczyń krwionośnych komórek nowotworowych, czyli angiogenezy. W kontekście antynowotworowego działania witaminy D najczęściej mówi się o nowotworze piersi, prostaty i jelita grubego, jednak należy zaznaczyć, że wiele ze wskazywanych mechanizmów ochronnych zostało wykazane jedynie w modelach zwierzęcych (FELDMAN i współaut. 2014). Na podstawie przeprowadzonych badań epidemiologicznych $z$ udziałem ludzi stwierdzono, że osoby zamieszkujace tereny oddalone od równika maja większe ryzyko wystapienia nowotworów piersi i prostaty, co można powiązać z gorszym stanem zaopatrzenia organizmu $\mathrm{w}$ witaminę $\mathrm{D}$ (GRANT 2012).

\section{WITAMINA D A RYZYKO WYSTAPIENIA ZESPOEU METABOLICZNEGO}

Zły stan zaopatrzenia organizmu w witaminę D może być także powiązany ze zwiększonym ryzykiem pojawienia się zespołu metabolicznego, czyli łącznego występowania otyłości brzusznej, zaburzeń tolerancji glukozy oraz metabolizmu lipidów i/lub podwyższonego ciśnienia krwi. Ju i współaut. (2014) w metaanalizie dotyczacej tego zagadnienia podkreślaja jednak, że takie zależności obserwuje się w badaniach przekrojowych, natomiast wyniki badań obserwacyjnych ich nie potwierdzaja. W zwiazku $z$ tym, istnieje konieczność prowadzenia randomizowanych badań eksperymentalnych w celu ustalenia, czy suplementacja witamina D może być skuteczna metoda zapobiegania zespołowi metabolicznemu. Jednym $z$ argumentów potwierdzających tę hipotezę może być fakt, że zespół metaboliczny jest rozpoznawany istotnie częściej w okresach mniejszego nasłonecznienia, czyli w zimie, co można powiąać $z$ gorszym stanem zaopatrzenia organizmu $\mathrm{w}$ witaminę $\mathrm{D}$ (STRANGE i współaut. 2015). Liczne badania wskazuja także na powiazanie niedoboru witaminy D z chorobami sercowo-naczyniowymi. PARKER i współaut. (2010) w metaanalizie uwzględniajacej wyniki 28 badań wykazali o 33\% mniejsze ryzyko wystapienia chorób sercowo-naczyniowych u osób $z$ wysokim poziomem witaminy D we krwi, w porównaniu do osób $z$ jej niskim poziomem. Mechanizm odpowiadajacy za to zjawisko nie jest jeszcze do końca poznany, jednak autorzy podaja, że może być on związany $z$ wpływem witaminy D na syntezę białek macierzy mitochondrialnej, które hamuja procesy kalcyfikacji naczyń krwionośnych. Co więcej, witamina D działa jak inhibitor cytokin prozapalnych, a także stymuluje syntezę przeciwzapalnej interleukiny-10. Wykazano także, że niski poziom witaminy D we krwi wpływa na zwiększona aktywność osi renina-angiotensyna, co prowadzi do podwyższonego ciśnienia krwi (WIMALAWANSA 2018).

\section{WITAMINA D A RYZYKO WYSTAPIENIA CUKRZYCY TYPU I I II}

Cukrzyca to jedno $z$ najpowszechniej występujących zaburzeń endokrynnych, objawiające się przede wszystkim podwyższonym poziomem glukozy we krwi. Wyróżnia się dwa główne typy cukrzycy: I i II. Najczęściej występuje typ II, który pojawia się zwykle u 
Tabela 1. Poziom wiedzy osób starszych na temat witaminy D w zależności od czynników socjo-demograficznych (brak różnic istotnych statystycznie pomiędzy analizowanymi grupami, test $\mathrm{Chi}^{2} p>0,05$ ).

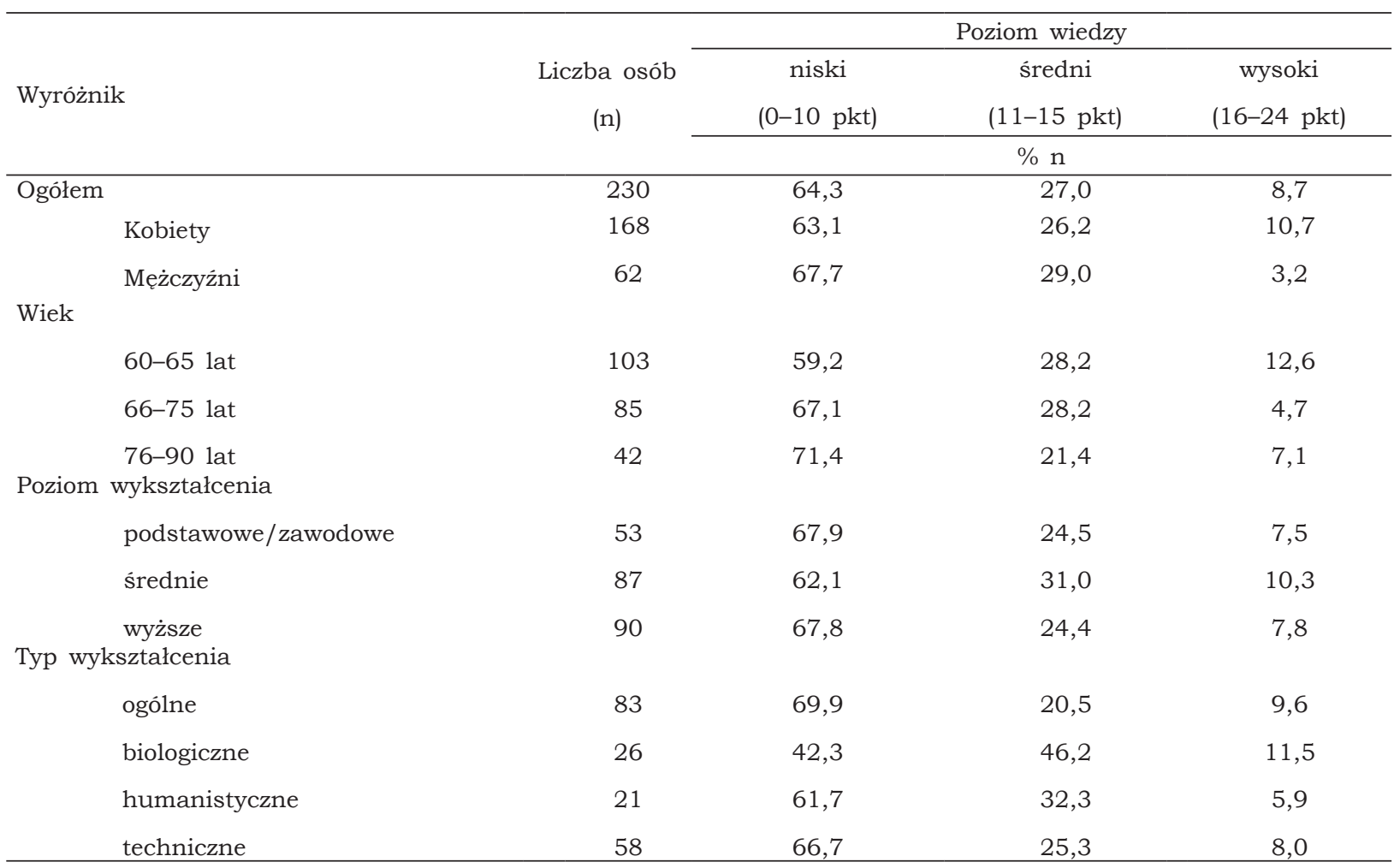

osób dorosłych w wyniku nieprawidłowego stylu życia, w tym żywienia, i jest związany $z$ opornościa tkanek na działanie insuliny, a także postępujacca dysfunkcją komórek $\beta$ trzustki. Typ I natomiast to choroba o podłożu autoimmunologicznym, której objawy pojawiają się przeważnie w wieku dziecięcym. W organizmie osoby chorej na cukrzycę typu I, w wyniku nieprawidłowej reakcji układu odpornościowego, dochodzi do niszczenia komórek $\beta$ trzustki wytwarzajacych insulinę. Pomimo różnych mechanizmów patogenezy, wyniki badań wskazują na istnienie zwiąku niedoboru witaminy D zarówno z cukrzyca typu I, jak i II (TAKIISHI i wspó1aut. 2010). Jak wykazano w badaniach obserwacyjnych, suplementacja witamina D kobiet ciężarnych, a także dzieci jest zwiazana z mniejszym ryzykiem wystapienia cukrzycy typu I w przyszłości, jednak w literaturze światowej brakuje badań eksperymentalnych na ten temat (PITTAS i DAWSON-HUGHES 2010). Ponadto, u osób z cukrzyca typu I, stan zaopatrzenia organizmu w witaminę D jest istotnie gorszy niż u osób zdrowych, co może być zwiąane $z$ uwarunkowaniami genetycznymi wpływającymi zarówno na ryzyko wystapienia cukrzycy, jak i stan odżywienia witamina D (COOPER i współaut. 2011). Natomiast wyniki badań dotyczace ryzyka za- chorowania na cukrzycę typu II przy różnym stanie zaopatrzenia organizmu w witaminę D nie sa jednoznaczne. $Z$ jednej strony $u$ pacjentów obserwowane sa sezonowe wahania glikemii (wzrost w miesiacach jesienno-zimowych, obniżenie w okresie wiosenno-letnim), a w badaniach interwencyjnych $z$ udziałem osób chorych stwierdzono korzystny wpływ suplementacji witamina D na tolerancję glukozy oraz zmniejszenie insulinooporności. Jednak w badaniach $z$ udziałem osób zdrowych nie stwierdzono wpływu suplementacji witamina D na glikemię, co sugerowałoby brak takich korzyści w ramach profilaktyki cukrzycy typu II, których można by się spodziewać ze względu na obecność receptorów witaminy $\mathrm{D}$ w komórkach $\beta$ trzustki oraz lokalna produkcję $1,25(\mathrm{OH})_{2} \mathrm{D}$ w tym narzadzie (MITRI i współaut. 2011).

\section{WITAMINA D A FUNKCJONOWANIE POZNAWCZE}

$\mathrm{Na}$ funkcjonowanie poznawcze wpływa szereg czynników zarówno modyfikowalnych, jak i niemodyfikowalnych. Stwierdzono, że ryzyko wystapienia zaburzeń funkcji poznawczych wzrasta $z$ wiekiem (w populacji osób $\geq 65$ roku życia częstość występowania jest na poziomie 5-10\%), znane sa 
Tabela 2. Poziom wiedzy osób starszych na temat witaminy D w zależności od parametrów związanych ze stanem zdrowia (brak różnic istotnych statystycznie pomiędzy analizowanymi grupami test $\left.\mathrm{Chi}^{2} p>0,05\right)$.

\begin{tabular}{|c|c|c|c|c|}
\hline \multirow{3}{*}{ Wyróżnik } & \multirow{3}{*}{$\begin{array}{c}\text { Liczba osób } \\
\text { (n) }\end{array}$} & \multicolumn{3}{|c|}{ Poziom wiedzy } \\
\hline & & $\begin{array}{c}\text { niski } \\
\text { (0-10 pkt) }\end{array}$ & $\begin{array}{c}\text { średni } \\
(11-15 \mathrm{pkt})\end{array}$ & $\begin{array}{c}\text { wysoki } \\
\text { (16-24 pkt) }\end{array}$ \\
\hline & & \multicolumn{3}{|c|}{$\% \mathrm{z} \mathrm{n}$} \\
\hline \multicolumn{5}{|l|}{ BMI } \\
\hline$<18,5 \mathrm{~kg} / \mathrm{m}^{2}$ & 10 & 60,0 & 30,0 & 10,0 \\
\hline $18,5-24,9 \mathrm{~kg} / \mathrm{m}^{2}$ & 93 & 60,2 & 26,9 & 12,9 \\
\hline $25-29,9 \mathrm{~kg} / \mathrm{m}^{2}$ & 96 & 68,8 & 26,0 & 5,2 \\
\hline $\begin{array}{r}\geq 30 \mathrm{~kg} / \mathrm{m}^{2} \\
\text { Choroby przewlekłe }\end{array}$ & 31 & 64,5 & 29,0 & 6,5 \\
\hline tak & 142 & 62,7 & 27,5 & 9,9 \\
\hline $\begin{array}{r}\text { nie } \\
\text { Osteoporoza }\end{array}$ & 88 & 67,0 & 26,1 & 6,8 \\
\hline tak & 11 & 63,6 & 18,2 & 9,1 \\
\hline $\begin{array}{l}\text { nie } \\
\text { Złamania w ostatnich } 5 \text { la }\end{array}$ & 219 & 64,4 & 27,4 & 8,7 \\
\hline tak & 41 & 70,7 & 17,1 & 12,2 \\
\hline $\begin{array}{c}\text { nie } \\
\text { Korzystanie } \mathrm{z} \text { porad lekars }\end{array}$ & 189 & 63,0 & 29,1 & 7,9 \\
\hline tak & 106 & 64,2 & 26,4 & 9,4 \\
\hline $\begin{array}{c}\text { nie } \\
\text { Porady dietetyka }\end{array}$ & 124 & 64,5 & 27,4 & 8,1 \\
\hline tak & 43 & 58,1 & 27,9 & 14,0 \\
\hline nie & 187 & 65,8 & 26,7 & 7,5 \\
\hline
\end{tabular}

także specyficzne genotypy, które moga predysponować do rozwinięcia zaburzeń (HUGo i GANGULI 2014). Istotnym czynnikiem modyfikowalnym, który stanowi obecnie obiekt wielu badań jest sposób żywienia i stan odżywienia, a jednym $z$ badanych aspektów jest rola witaminy $D$. Jej aktywna forma $1,25(\mathrm{OH})_{2} \mathrm{D}$ jest obecna $\mathrm{w}$ płynie mózgowo-rdzeniowym, a jej receptory znajduja się również w ośrodkowym układzie nerwowym, co może wskazywać na istotna rolę w prawidłowym funkcjonowaniu poznawczym. Wykazano również stymulujący wpływ witaminy D na syntezę neurotransmiterów, czynników neuroprotekcyjnych i glutationu (ANNWEILER i współaut. 2013). Wyniki badań epidemiologicznych wskazuja na większe ryzyko wystapienia zaburzeń funkcji poznawczych u osób $z$ poziomem witaminy $D<50 \mathrm{nmol} / 1$ (BAILON i współaut. 2012). W metaanalizie, w której uwzględniono dane pochodzace od ponad 28 tysięcy osób wykazano, że już stężenie $25(\mathrm{OH}) \mathrm{D}$ we krwi na poziomie 25-35 ng/ $\mathrm{ml}$ jest zwiazane $\mathrm{z} 31 \%$ mniejszym ryzykiem wystapienia choroby Alzheimera, w porówna- niu do stężenia <10 ng/ml (JAYEDI i współaut. 2018).

\section{WIEDZA OSÓB STARSZYCH DOTYCZACA WITAMINY D}

Biorac pod uwage liczne funkcje witaminy D oraz jej korzystne działanie u osób starszych, ważne jest osiagnięcie i utrzymywanie prawidłowego stanu zaopatrzenia organizmu $\mathrm{w}$ tę witaminę. $Z$ tego względu szczególnie istotna wydaje się ocena wiedzy seniorów na temat witaminy $\mathrm{D}$, w tym zasad jej suplementacji, źródeł pokarmowych i roli jaka pełni w organizmie. Badanie przeprowadzone w 2015 r. przez zespół z Katedry Żywienia Człowieka SGGW na terenie przychodni lekarskich oraz w czasie zajęć uniwersytetów trzeciego wieku (UTW) obejmowało 230 osób w wieku >60 lat, mieszkających w domach rodzinnych (niezinsytucjolizowanych) w Warszawie. Seniorów zapytano m.in. o źródła pokarmowe witaminy $\mathrm{D}$, syntezę skórna, zapotrzebowanie oraz o funkcje pełnione przez tę witaminę. Poziom wiedzy badanych 
Tabela 3. Rozkład odpowiedzi na pytania o źródła witaminy D dla organizmu człowieka.

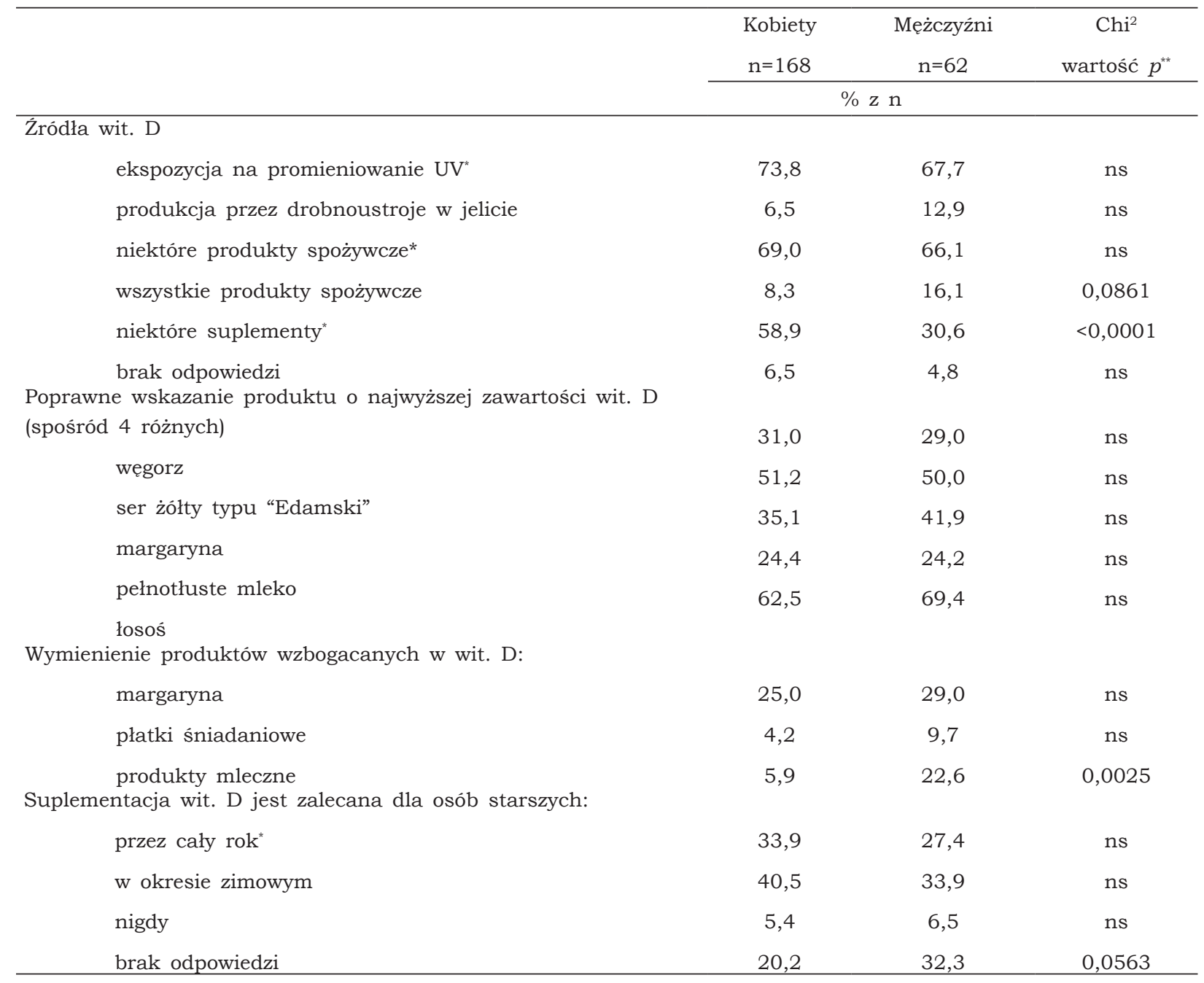

*poprawna odpowiedź, ** ns - brak różnic istotnych statystycznie.

osób na temat witaminy D był niewystarczający (Tabela 1), tj. ponad $64 \%$ osób miało wiedze na niskim poziomie, a niespełna 9\% respondentów reprezentowało poziom wysoki. W badaniu tym nie wykazano istotnych statystycznie zależności pomiędzy poziomem wiedzy a wybranymi cechami socjo-demograficznymi (Tabela 1), ani zwiazanymi ze stanem zdrowia (Tabela 2). Jedynie wśród osób o wykształceniu biologicznym było więcej respondentów o średnim i wysokim poziomie wiedzy niż wśród pozostałych wolontariuszy $(p=0,0127)$. Ponadto, nieco większy odsetek kobiet niż mężczyzn zaliczono do grupy o wysokim poziomie wiedzy, ale ta zależność miała charakter tendencji $(p=0,0793)$. Trzeba podkreślić, że badanie nie dotyczyło populacji ogólnej ponieważ przeprowadzono je w Warszawie, grupa badana nie była zbyt liczna i przeważały $\mathrm{w}$ niej kobiety, a ankietowanymi byli pacjenci przychodni lekarskich oraz słuchacze uniwersytetów trzeciego wieku. Mogły być to osoby bardziej zainteresowane zdrowiem i jego zwiazkiem $z$ żywieniem niż osoby starsze $z$ populacji ogólnej. Uzyskane w tym badaniu wyniki potwierdzaja wcześniejsze doniesienia innych autorów. Jak wskazuje CHRISTIDES (2018) w przegladzie piśmiennictwa dotyczacym stanu wiedzy na temat witaminy D wśród osób starszych, większość seniorów zdaje sobie sprawę $z$ istotnej roli pełnionej przez cholekalcyferol $\mathrm{w}$ organizmie, jednak osoby szczególnie narażone na niedobór charakteryzował niższy poziom wiedzy, co wydaje się tym bardziej niepokojace.

Odnosząc się do różnych zagadnień dotyczacych witaminy D stwierdzono, że większość uczestników omawianego badania $(72,2 \%)$ prawidłowo wskazała ekspozycję na światło słoneczne jako ważne źródło witaminy D dla organizmu człowieka, a ponad połowa $(51,3 \%)$ ankietowanych była również świadoma roli suplementów diety oraz tego, że witamina D nie występuje we wszystkich 
Tabela 4. Rozkład odpowiedzi na pytania o wpływ witaminy D na zdrowie i czynniki ryzyka niedoboru.

\begin{tabular}{|c|c|c|c|c|}
\hline & $\begin{array}{l}\text { Kobiety } \\
n=168\end{array}$ & $\begin{array}{c}\text { Mężczyźni } \\
n=62 \mathrm{~s}\end{array}$ & Ogółem & $\begin{array}{c}\text { Chi2 } \\
\text { wartość p* }\end{array}$ \\
\hline & \multicolumn{3}{|c|}{$\% \mathrm{zn}$} & \\
\hline \multicolumn{5}{|l|}{ Skutki niedoboru witaminy D: } \\
\hline osteopenia & 48,8 & 40,3 & 46,5 & ns \\
\hline osteoporoza & 79,8 & 75,8 & 78,7 & ns \\
\hline nowotwór & 18,5 & 21,0 & 19,1 & $\mathrm{~ns}$ \\
\hline cukrzyca typu I & 23,2 & 33,9 & 26,1 & ns \\
\hline inne fałszywe odpowiedzi & 30,3 & 25,8 & 29,1 & ns \\
\hline \multicolumn{5}{|l|}{ Czynniki ryzyka niedoborów - odpowiedzi prawidłowe: } \\
\hline zanieczyszczenie powietrza & 38,1 & 38,7 & 38,2 & ns \\
\hline nadwaga & 44,6 & 38,7 & 43,0 & $\mathrm{~ns}$ \\
\hline starszy wiek & 65,5 & 66,1 & 65,6 & ns \\
\hline choroby watroby i nerek & 16,7 & 67,7 & 30,4 & $<0,0001$ \\
\hline \multicolumn{5}{|l|}{ Czynniki ryzyka niedoborów - odpowiedzi błędne: } \\
\hline małe spożycie warzyw i owoców & 45,8 & 37,1 & 43,5 & ns \\
\hline regularne spożywanie ryb morskich & 8,9 & 6,5 & 8,2 & $\mathrm{~ns}$ \\
\hline regularne spożywanie pełnotłustego nabiału & 5,9 & 6,5 & 6,1 & ns \\
\hline ekspozycja na promieniowanie UV & 8,9 & 12,9 & 10,0 & ns \\
\hline mała aktywność fizyczna & 52,4 & 38,7 & 48,7 & 0,0656 \\
\hline
\end{tabular}

*ns - brak różnic istotnych statystycznie

rodzajach żywności $(68,3 \%)$ (Tabela 3). Warto jednak zaznaczyć, że kobiety istotnie częściej wskazywały suplementy diety jak źródło witaminy $\mathrm{D}$, w porównaniu do mężczyzn $(58,9 \%$ vs. $30,6 \%$ ), i nieco rzadziej wszystkie produkty spożywcze (tendencja). Natomiast nie było różnic $\mathrm{w}$ odpowiedziach kobiet i mężczyzn, gdy badani byli proszeni o wskazanie produktu zawierajacego najwięcej witaminy D spośród czterech podanych w pięciu zestawach. Najwięcej osób poprawnie wskazało, że był to łosoś $(64,3 \%)$. Respondenci nie byli także świadomi jakie produkty dostępne na rynku sa wzbogacane witamina $\mathrm{D}$ (odpowiedź na pytanie otwarte): jedynie $26 \%$ podało margarynę, a 5,6\% płatki zbożowe. Najwięcej osób $z$ badanej grupy uważało, że suplementować witaminę $\mathrm{D}$ w wieku starszym należy tylko w zimie (38,7\%), natomiast 5,6\% badanych nie wiedziało w ogóle o konieczności suplementacji. Podobne wyniki uzyskano w we wcześniejszym badaniu polskich autorów (SARAN i DUDA 2010) przeprowadzonym z udziałem 1045 mieszkańców Poznania w wieku >60 lat, w którym również stwierdzono niezadowalajacy poziom wiedzy seniorów. $\mathrm{Na}$ pytanie o żywieniowe źródła witaminy Do- raz o możliwość skórnej syntezy witaminy D poprawnie odpowiedziało odpowiednio 65,4\% oraz $44,4 \%$ osób ( $w$ obu przypadkach kobiety udzieliły poprawnej odpowiedzi istotnie częściej niż mężczyźni). Również dane autorów z Wielkiej Brytanii potwierdzają konieczność prowadzenia działań edukacyjnych: w grupie 209 osób (średni wiek 34,9 \pm 12 lat) uzyskany odsetek poprawnych odpowiedzi wynosił średnio 56,6\%, natomiast $57 \%$ badanych deklarowało, że nie przyjmuje suplementów witaminy D (O’CONNOR i współaut. 2018). Ankietowani poprawnie wskazywali ekspozycję słoneczna, suplementy i żywność jako źródła witaminy D (odpowiednio: 99\%, $87 \%$ i $84 \%$ ), jednak tylko połowa badanych poprawnie wybrała olej rybi jako produkt zawierający największe ilości witaminy $\mathrm{D}$. Natomiast podobnie jak $\mathrm{w}$ badaniu własnym, około połowa ankietowanych błędnie wybrała warzywa i owoce uznając je za dobre źródło witaminy D. Aż 86\% uczestników zadeklarowało, że chciałoby dowiedzieć się więcej na temat witaminy D. Trudno jednak bezpośrednio porównywać wyniki O'CONNOR i współaut. (2018), ponieważ we wspomnianym badaniu oceniano wiedzę w populacji ogólnej (auto- 
Tabela 5. Rozkład poprawnych odpowiedzi na pytanie typu "prawda/fałsz" ze stwierdzeniami dotyczącymi witaminy D (brak różnic istotnych statystycznie między kobietami i mężczyznami, test Chi ${ }^{2}$ $p>0,05)$.

Stwierdzenie

\begin{tabular}{ll} 
& \\
\hline Prawdziwe: & \\
Witamina D pobudza wchłanianie wapnia z przewodu pokarmowego & 56,5 \\
Przedawkowanie prowadzi do zaburzeń w gospodarce wapniem & 31,7 \\
Niedobory stwierdza się u wielu osób starszych & 60,9 \\
Prawidłowy poziom wit. D we krwi zmniejsza ryzyko upadków & 30,9 \\
Fałszywe: & 24,3 \\
Najlepszym źródłem wit. D są warzywa i owoce & 25,7 \\
Wit. D rozkłada się w czasie gotowania i smażenia produktów \\
Nie istnieje możliwość przedawkowania wit. D \\
Wit. D należy do grupy witamin rozpuszczalnych w wodzie
\end{tabular}
$\% \mathrm{n}$
Poprawne odpowiedzi

amina D nie jest rozpuszczalna w wodzie $(14,8 \%)$.

$\mathrm{Na}$ konieczność prowadzenia działań edukacyjnych wskazywały już wcześniejsze badania OUDSHOORN i współaut. (2011), którzy stwierdzili, ̇̇e lepszy poziom wiedzy na temat witaminy $\mathrm{D}$ i wapnia był zwiazany $z$ wyższym poziomem witaminy $\mathrm{D} w$ surowicy krwi, a także wyższym spożyciem wapnia wraz $z$ dietą. Do badania zakwalifikowano 426 niezinstytucjonalizowanych osób w wieku $\geq 65$ mieszkających w Holandii, spośród których jedynie 38\% zadeklarowało, że słyszało kiedykolwiek o witaminie D. Jedynie 34\% spośród badanych poprawnie wskazało, że witamina D wpływa na stan kośćca, a jeśli chodzi o źródła witaminy $D$, to najwięcej osób wskazywało na dietę (60\%) i ekspozycję słoneczna $(30 \%)$. W porównaniu do seniorów $z$ Holandii, wyniki uzyskane $z$ udziałem polskich seniorów wskazuja na dużo wyższy poziom wiedzy w Polsce. W badaniu przeprowadzonym wśród 232 seniorów uczęszczających na zajęcia UTW w Warszawie 75,4\% respondentów deklarowało chęć skorzystania $z$ usług dietetyka, a aż 83,6\% twierdziło, że poradnictwo dietetyczne jest potrzebne lub bardzo potrzebne osobom w podeszłym wieku (PTASIŃSKA i współaut. 2014). Wskazuje to na zainteresowanie osób starszych zdrowym żywieniem i pogłębianiem wiedzy na ten temat, co stwarza dogodne warunki do planowania programów edukacyjnych.

\section{PODSUMOWANIE}

Witamina D w organizmie osób starszych odgrywa szczególna rolę ze względu na ob- 
niżanie ryzyka osteoporozy, zaburzeń funkcji poznawczych oraz prewencję upadków. Seniorzy są również grupa o podwyższonym ryzyku wystapienia niedoborów witaminy $\mathrm{D}$ przez obniżona syntezę skórna cholekalcyferolu. Biorac pod uwagę powyższe doniesienia oraz wyniki badania własnego, które wskazuja na niewystarczajacy poziom wiedzy osób starszych na temat źródeł i funkcji witaminy D oraz konieczności jej suplementacji, istnieje potrzeba planowania oraz wdrażania skutecznych programów edukacyjnych dla seniorów na ten temat.

\section{Streszczenie}

Witamina D pełni liczne funkcje w organizmie - o wielu $\mathrm{z}$ nich wiadomo od dawna, jednak stanowi ona obecnie przedmiot intensywnych badań naukowych, w związku z czym wciąż poznajemy jej nowe role. Osoby starsze to grupa szczególnie narażona na ryzyko niedoborów tej witaminy, głównie ze względu na fakt, że wraz z wiekiem obniża się wydajność syntezy skórnej. W artykule przedstawiono funkcje witaminy $\mathrm{D} w$ organizmie $\mathrm{z}$ uwzględnieniem jej roli dla seniorów i na tym tle przeanalizowano dane o wiedzy osób starszych dotyczącej tej witaminy. W badaniu wzięło udział 230 osób w wieku 60-90 lat, spośród których większość stanowily kobiety (73\%). Stwierdzono, że wiedza osób starszych na temat źródeł, funkcji oraz ryzyka niedoborów jest niewystarczająca: 64\% badanych osób charakteryzowało się niskim poziomem wiedzy, a jedynie $8 \%$ miało ten poziom wysoki. Należy więc prowadzić edukację żywieniową w grupie osób starszych dotycząca znaczenia i zapotrzebowania na witaminę $\mathrm{D}$.

\section{LITERATURA}

AnNweiler C., MONTERO-Odasso M., LlewElLYN D. J., RICHARD-DEvantoy S., DuQue G., BEAUCHET O., 2013. Meta-analysis of memory and executive dysfunctions in relation to vitamin D. J. Alzheimers Dis. 37, 147-171.

Bailon C., Griffith L. E., Stifler L., Henderson M., Patterson C., Heckman G., Llewellyn D. J., RAINA P., 2012. Vitamin D, cognition, and dementia. A systematic review and meta-analysis. Neurology 79, 1397-1405.

Bandera MERchan B., MoRCILlo S., Martin-NuñeZ G., TINAHONES F. J., MACÍAS-GONZÁlEZ M. 2017. The role of vitamin $D$ and VDR in carcinogenesis: Through epidemiology and basic sciences. J. Steroid. Biochem. Mol. Biol. 167 203-218.

BruYere O., CAVAlier E., Souberbielle J. C., BiSCHOFF-FERRARI H. A., BEAUDART C., BUCKINX F., Reginster J. Y., Rizzoli R., 2014. Effects of vitamin $D$ in the elderly population: current status and perspectives. Arch. Public Health. 72, doi: 10.1186/2049-3258-72-32.

CHRISTIDES T., 2018. Older adults' beliefs, knowledge and preferences for achieving healthy vitamin $D$ status: a narrative review. Geriatrics 3, doi: $10.3390 /$ geriatrics3020026.

Cooper J. D., SMYTH D. J., WAlKer N. M., STEVens H., BurRen O. S., Wallace C., GReissl C., Ramos-Lopez E., Hypponen E. , DunGER D. B., SPECTOR T. D., OUWEhAND W. H., WANG T. J., KLAUS BADENHOOP K., TODD J. A., 2011. Inherited variation in vitamin $D$ genes is associated with predisposition to autoimmune disease type 1 diabetes. Diabetes 60, 16241631.

DHaliwal R., Aloia J. F., 2017. Effect of vitamin $D$ on falls and physical performance. Endocrinol. Metab. Clin. North Am. 46, 919-933.

FELDMAN D., KRISHAN A. V., SWAMI S., GIOVANNUCCI E., FELDMAN B. J., 2014. The role of vitamin $D$ in reducing cancer risk and progression. Nat. Rev. Cancer 14, 342-357.

GALlaGHER J. C., 2016. Vitamin D and falls - the dosage conundrum. Nat. Rev. Endocrinol. 12, 680-684.

GRANT W. B., 2012. Ecological studies of the UVB-vitamin D-cancer hypothesis. Anticancer Res. 32, 223-236.

GRYGIEL-GÓRNIAK B., PUSZCZEWICZ M., 2014. Witamina D-nowe spojrzenie $w$ medycynie $i$ reumatologii. Postepy Hig. Med. Dosw. 68, 359-368.

HALFON M., PHAN O., TETA D., 2015. Vitamin D: A Review on its effects on muscle strength, the risk of fall, and frailty. Biomed. Res. Int. 2015, doi: $10.1155 / 2015 / 953241$.

HILl T. R., ASPRAY T. J., FRANCIS R. M., 2013. Vitamin $D$ and bone health outcomes in older age. Proc. Nutr. Soc. 72, 372-380.

Holick M. F., 2017. The vitamin $D$ deficiency pandemic: Approaches for diagnosis, treatment and prevention. Rev. Endocr. Metab. Disord. $18,153-165$.

Hugo J., Ganguli M., 2014. Dementia and cognitive impairment: epidemiology, diagnosis, and treatment. Clin. Geriatr. Med. 30, 421-442.

JAYEDI A., RASHIDY-POUR A., SHAB-BIDA S., 2018. Vitamin D status and risk of dementia and Alzheimer's disease: A meta-analysis of dose-response. Nutr. Neurosci., doi: 10.1080/1028415X.2018.1436639.

Jennings A., CASHMAN K. D., GILlings R., CASSIDY A., Tang J., Fraser W., Dowling K. G., Hull G. L. J., BERENDSEN A. A. M., DE GROOT L. C. P. G. M., Pietruszka B., WierzBicka E., OSTAN R., BAZZOCCHI A., BATTISTA G., CAUMON E., MEUnier N., MAlpuech-BrugËe C., FRANCESCHI C., SANTORO A., FAIRWEATHER-TAIT S. J., 2018. A Mediterranean-like dietary pattern with vitamin D3 $(10 \mu \mathrm{g} / \mathrm{d})$ supplements reduced the rate of bone loss in older Europeans with osteoporosis at baseline: results of a 1-y randomized controlled trial. Am. J. Clin. Nutr. 108, 633-640.

Ju S. Y., JEONG H. S., KIM D.-H., 2014. Blood vitamin $D$ status and metabolic syndrome in the general adult population: a dose-response meta-analysis. J. Clin. Endocrinol. Metab. 99, 1053-1063.

LANSKE B., RaZZAQue M. S., 2007. Vitamin D and aging: old concepts and new insights. J. Nutr. Bioch. 18, 771-777.

LIPS P., VAN SCHOOR N., 2011a. The effect of vitamin $D$ on bone and osteoporosis. Best Pract. Res. Clin. Endocrinol. Metab. 25, 585-591.

LIPS P., VAN SCHOOR N., 2011b. Worldwide vitamin $D$ status. [W:] Vitamin D. FELDMAN D., Wesley PIKE J., ADAMS J. S. (red.). Academic Press., USA, 947-963.

MAKARA-STUDZIN̂SKA M., KRYŚ-NOSZCZYK K., 2012. Oblicza starości - przeglad piśmiennictwa. Psychogeriatria Polska 9, 77-86.

Mitri J., MURARU M. D., PITTAS A. G., 2011. Vitamin $D$ and type 2 diabetes: a systematic review. Eur. J. Clin. Nutr. 65, 1005-1015.

O'CONNOR C., GLATT D., WhiTe L., INIESTA R. R., 2018. Knowledge, attitudes and perceptions towards vitamin $D$ in a UK adult population: a cross-sectional study. Int. J. En- 
viron. Res. Public Health 15, doi: 10.3390/ ijerph 15112387.

OUDSHOORN, C., HARTHOLT A., KLAAS A. H., VAN LeEuwen J., Colin E., Velde N., VAN DeR CAMMEN T., 2011. Better knowledge on vitamin $D$ and calcium in older people is associated with a higher serum vitamin $D$ level and a higher daily dietary calcium intake. Health Educ. J. 71, 1-9.

Parker J., Hashmi O., DutTon D., Mavrodaris A., StRANGES S., NGIANGA-BAKWIN K., ClaRKe A., FRANCO O. H., 2010. Levels of vitamin $D$ and cardiometabolic disorders: Systematic review and meta-analysis. Maturitas 65, 225-236.

PitTas A.G., Dawson-Hughes B., 2010. Vitamin D and diabetes. J. Steroid. Biochem. Mol. Biol. $121,425-429$

Ptasińska O., Bialecka A., StelmaszczyK-Kusz A., 2014. Ocena potrzeb osób starszych $w$ zakresie poradnictwa dietetycznego. Geriatria 8, $1-8$.

REID I. R., Bolland M. J., GREY A., 2014. Effects of vitamin $D$ supplements on bone mineral density: a systematic review and meta-analysis. Lancet 383, 146-155.

RusińsKa A., PŁUdOWsKi P., WALCZAK M., BORSZEWSKA-KORNACKA M. K., BOSSOWSKI A, CHLEBNA-SoKót D., CZECH-Kowalska J., DOBRZAŃSKA A., Franek E., Helwich E., Jackowska T., KALINA M. A., KONSTANTYNOWICZ J., KSIAŻYYK J. i współaut., 2018a. Vitamin D supplementation guidelines for general population and groups at risk of vitamin $D$ deficiency in Poland - recommendations of the Polish Society of Pediatric Endocrinology and Diabetes and the expert panel with participation of national specialist consultants and representatives of scientific societies - 2018 update. Front. Endocrinol. 9, doi: 10.3389/fendo.2018.00246.

RUSiŃSKA A., PŁUdOWSKI P., WALCZAK M., BORSZEWSKA-KORNACKA M. K., BOSSOWSKI A., Chlebna-Sokó D., CZech-Kowalska J., DoBRZAŃSKa A., FRANEK E., HELWICH E., JACKOW-
SKA T., Kalina M., KOnSTANTYNOWICZ J., KSIAŻYK J., i współaut., 2018b. Vitamin D sup plementation guidelines for Poland - a 2018 update. Post. Neonatol. 24, doi: 10.31350/ postepyneonatologii/2018/1.

SARAN A., DUDA G., 2010. Ocena wiedzy osób starszych dotyczaca witamin i składników mineralnych. Bromat. Chem. Toksykol. 43, 6065.

Strange R. C., Shipman K. E., Ramachandran S., 2015. Metabolic syndrome: A review of the role of vitamin $D$ in mediating susceptibility and outcome. World J. Diabetes 6, 896-911.

SZYMAŃSKI F. M., BOMBA-OPOŃ D. A., ŁĘGOSZ P., GŁOGOWSKA-SZELAG J., BARAN W., SZPIETOWSKI J. C., KOS-KudŁA B., FILIPIAK K. J., KOZŁOWSKA-WOJCIECHOWSKA M., 2015. Miejsce witaminy $D$ w codziennej praktyce klinicznej - interdyscyplinarne stanowisko ekspertów. Forum Medycyny Rodz. 9, 423-434.

TAKiIShi T., Gysemans C., Bouillon R., MathieU C., 2010. Vitamin $D$ and diabetes. Endocrinol. Metab. Clin. North. Am. 38, 179-206.

VAN SCHOOR N., LIPS P., 2017. Global overview of vitamin $D$ status. Endocrinol. Metab. Clin. North Am. 46, 845-870.

WimalaWANSA S. J., 2018. Vitamin $D$ and cardiovascular diseases: Causality. J. Steroid Biochem. Mol. Biol. 175, 29-43.

WYSKIDA M., WIECZOROWSKA-TOBIS K., CHUdEK J., 2017. Czestość oraz czynniki sprzyjajace wy stepowaniu niedoborów witaminy $D$ w wieku podeszłym. Postepy Hig. Dosw. 71, 198-204.

WYSKIDA M., OWCZAREK A., SZYBALSKA A., BRZOZOWSKA A., SZCZERBOWSKA I., WIECZOROWSKA-TOBIS K., PUZIANOWSKA-KUŻNICKA M., FRANEK E., Mossakowska M., GrodZICKI T., WIECEK A., Olszanecka-Glinianowicz M., CHudeK J., 2018. Socio-economic determinants of vitamin $D$ deficiency in the older Polish population: results from the PolSenior study. Public Health Nutr. 21, 1995-2003.

KOSMOS Vol. 68, 2, 283-292, 2019

Dominika Granda, Anna ŻyfKa-Zagrodzińska, Paulina Renc-Smolewska, Maria Szmidt, ElżBieta Wierzbicka, ANNA BRZOZOWSKA

Department of Human Nutrition, Faculty of Human Nutrition and Consumer Sciences, Warsaw University of Life Sciences-SGGW, 159C Nowoursynowska Str., 02-776 Warszawa,E-mail: dominika_granda@sggw.pl

VITAMIN D IN THE ELDERLY - FUNCTIONS, RISK OF DEFICIENCY AND SENIORS KNOWLEDGE

Summary

Vitamin D plays numerous functions in the human body - many of them have been known for a long time, but presently further intense studies lead continuously to the discovery of its new roles. The older people are a group at high risk of vitamin D deficiency, mainly due to the fact that its biosynthesis in the skin decreases with age. This paper presents the functions of vitamin D in the body, with special emphasis on the risk of its deficiency in the elderly. In this context the knowledge of older people about vitamin D was surveyed and analyzed. The survey included 230 respondents aged $60-90$, most of whom were women $(73,0 \%)$. Our results revealed that the knowledge of the elderly about the sources, functions and risk of deficiency is insufficient: $64 \%$ of respondents were characterized by a low level of knowledge, and only $8 \%$ had a high level of knowledge. There is thus a need for nutritional education of old people on the role of vitamin D, risks of its deficiency and requirement of supplementation.

Key words: vitamin D, elderly, nutritional knowledge 